larger molecules are the more abundant ${ }^{3}$. The passage of this protein from the blood into the ovary raises an interesting problem. Either the blood hæmoglobin must be rapidly broken down and the products rapidly resynthesized in the ovary, or else the hæmoglobin molecule as such crosses the cell membranes. This would not be the sole case where the passage of a protein molecule across a cell mem. brane is suspected. Other examples are found in the secretion of hormones and enzymes, virus penetration and the particularly relevant case of the acquisition of passive immunity in birds' eggs. Here the antitoxin passes from the blood serum of the bird into the eggs ${ }^{4,5}$.

A full account of this work will be published elsewhere. I wish to express my sincere thanks to Prof. H. Munro Fox for his interest and advice.

Eussabeth I. B. Dreser

Bedford College,

University of London.

Oct. 7.

1 Fox, H. Munro, Proc. Roy. Soc., B, 185, 195 (1948).

- Teissier, G., C.R. Soc. Biol., Paris, 109, 813 (1932).

- Svedberg, T., and Friksson-Quensel, I.-B., J. Amer. Chem. Soc., 66, 1700 (1934).

- Fraser, D. T., Jukes, T. H., Branion, H. D., and Halpern, K. C., J. Immunol., 28, 437 (1934).

s Andrewes, C. H., J. Path. and Bact., 48, 225 (1939).

\section{Effect of Carbon Dioxide on Availability of Manganese in Soil Producing Manganese Deficiency}

A series of experiments, extending over several years, in which potato plants were grown both in pots and in the field, in soil producing manganese deficiency, from the recently drained lake-bed at East Malling Research Station, has led us to suspect the presence of some hitherto unexplained factor influencing manganese availability. The soil in question is an alluvial deposit containing a large amount of calcium carbonate and organic matter and has a $p H$ of $8 \cdot 0-8 \cdot 5$. The soil contains ample manganese, as simple extractions in Morgan's solution yield considerably more than 50 p.p.m. of manganese on a dry soil basis. This, however, is only a small fraction of the total, as is shown by extractions with strong acid. The amount of manganese available to the plant is, on the other hand, very small, since plants containing less than 1 p.p.m. on a fresh weight basis and showing acute deficiency symptoms are of common occurrence in certain areas of the lake-bed. Attempts to reproduce these conditions using the same soil in pot culture never succeeded in producing plants showing such marked symptoms or low manganese contents, although the soil $p H$ was maintained between 8.0 and 8.5 by irrigating with water saturated with calcium carbonate. Water extracts of soil taken either from pots or the lake-bed itself showed negligible amounts of extractable manganese, although the plants grown in pot culture in the summer of 1948 showed no manganese deficiency, while those grown in 1947 were much less deficient than those growing on the lake-bed.

Consideration of these facts led to the hypothesis that local accumulations of carbon dioxide within the root-masses might render manganese available without producing perceptible changes on the $p H$ of the soil as a whole. The following experiment was therefore carried out. Some uniformly mixed soil (water content $9 \cdot 0$ per cent) was collected and finely ground. Portions of $250 \mathrm{mgm}$. each were weighed out into $150 \mathrm{ml}$. conical hard-glass flasks, well corked, and were left in contact for forty-eight hours with high-grade water re-distilled in quartz. The water used was divided into two parts, one of which was saturated with acid-free carbon dioxide at $20^{\circ} \mathrm{C}$. and the other boiled. Mixtures in varying proportions were used, keeping the total volume at $25 \mathrm{ml}$. A flask was also set up in which the water was kept saturated with carbon dioxide during the extraction. After extraction the liquid was centrifuged to remove soil particles, and the $p H$ and amount of manganese extracted determined. The results are given in the accompanying table.

\begin{tabular}{|c|c|c|c|}
\hline $\begin{array}{c}\text { ml. bolled } \\
\text { water }\end{array}$ & $\begin{array}{c}\text { ml. water sat- } \\
\text { urated with CO. }\end{array}$ & $\begin{array}{c}\text { p.p.m. of Mn } \\
\text { extracted calc. } \\
\text { on dry soil }\end{array}$ & $p$ H of extract \\
\hline 25 & - & $<0 \cdot 1$ & $8 \cdot 0-8 \cdot 5$ \\
24 & 1 & $<0 \cdot 1$ & $8 \cdot 0-8 \cdot 5$ \\
23 & 2 & $<0 \cdot 1$ & $8 \cdot 0-8 \cdot 5$ \\
21 & 4 & $<0 \cdot 1$ & $8 \cdot 0-8 \cdot 5$ \\
17 & 16 & $0 \cdot 4$ & $8 \cdot 0$ \\
9 & 25 & $2 \cdot 6$ & $7 \cdot 5$ \\
- & 25 kept sat. & $22 \cdot 0$ & $7 \cdot 5$ \\
& with CO, & & $6 \cdot 0$ \\
\hline
\end{tabular}

Owing to the extremely localized accumulation of carbon dioxide likely to occur in the soil, and the large excess of calcium carbonate present, no general changes in $p H$ have been detected in the pot cultures, which remained uniformly above $p H \mathbf{H} \cdot 0$.

The liberation of manganese by these local accumulations of carbon dioxide would go far to account for the patchy distribution of symptoms found in the field and the higher manganese contents of pot plants with a more compacted root system. Owing to the rain early in the summer of 1948 the soil of the pots was saturated with water for several weeks, while in 1947 these conditions did not occur, which may explain the observed differences in manganese uptake.

\section{B. D. Bolas \\ G. B. Portsmouth}

Research Institute of Plant Physiology, Imperial College of Science,

London, S.W.7. Sept. 17.

\section{Protection of Grain against Weevils}

To-DAY, the losses of foodstuffs caused by insects, principally weevils, often disregarded in pre-war days, cannot be overlooked. A conservative estimate has been made that on the average losses of ten per cent of all stored food are caused by insects ${ }^{1}$. In the tropics the life-cycle of weevils and other insect pests is accelerated as the temperatures are close to the optimum and, furthermore, breeding is continuous throughout the year, so that the losses can attain appalling proportions-samples of grain offered for sale have been seen in which more than 50 per cent of the individual grains have been seriously damaged. In such infested grain there is a further attack by the flour beetle, Tribolium castaneum, which spoils the little good grain remaining by the taint.

During the last few years investigations have been in progress on inert dusts of local origin, some of which, notably diatomite, have been found to give 